ятия. Предложен и обоснован подход к обеспечению конкурентоспособности предприятия на основе определения предельной производительности труда, основанной на определении роста объемов продукции с использованием дополнительной единицы труда при других фиксированных условиях. Этот подход стимулирует предприятия оптимизировать ресурсы на базе применения дополнительной работы или вытеснения неэффективной работы и достижения уровня предельной производительности.

Практическая значимость. Результаты исследования могут быть использованы для дальнейших научных разработок в данном направлении, а также в практической деятельности машиностроительных предприятий как элемент повышения конкурентоспособности предприятия, основанный на экономическом базисе показателя производительности труда.

UDC 656.2

S. M. Turpak ${ }^{1}$, Dr. Sc. (Tech.), Prof., orcid.org/0000-0003-3200-8448,

I. O. Taran ${ }^{2}$, Dr. Sc. (Tech.), Prof., orcid.org/0000-0002-3679-2519,

O. V. Fomin ${ }^{3}$, Dr. Sc. (Tech.), Assoc. Prof., orcid.org/0000-0003-2387-9946,

O. O. Tretiak ${ }^{2}$, Cand. Sc. (Tech.), Assoc. Prof., orcid.org/0000-0002-6991-0235
Обоснован подход, который использует в базисе показателя производительности труда сокращение времени оборота продукции или логистического цикла, что непосредственно связано с экономией времени. В результате предприятие при тех же ресурсах живого и овеществленного труда получает высокие показатели производительности труда, что влияет на увеличение стоимости активов и показатели эффективности работы предприятия, в первую очередь, на рентабельность реализованной продукции.

Ключевые слова: машиностроение, производительность труда, конкурентоспособность, рентабельность активов, рентабельность реализованной продукции

Рекомендовано до публікації докт. екон. наук I.В. Свиноусом. Дата надходження рукопису 09.12.17.

DOI: $10.29202 /$ nvngu/2018-1/3

1-Zaporizhzhya National Technical University, Zaporizhia, Ukraine, e-mail: turpak@i.ua

2 - National Mining University, Dnipro, Ukraine

3 - The State University of Transport Economy and Technologies, Kyiv, Ukraine

\title{
LOGISTIC TECHNOLOGY TO DELIVER RAW MATERIAL FOR METALLURGICAL PRODUCTION
}

С. М. Турпак ${ }^{1}$, д-р техн. наук, проф., orcid.org/0000-0003-3200-8448, I. О. Таран ${ }^{2}$, д-р техн. наук. проф., orcid.org/0000-0002-3679-2519, О. В. Фомін ${ }^{3}$, д-р техн. наук. доц., orcid.org/0000-0003-2387-9946, O. О. Третяк ${ }^{2}$, канд техн. наук. доц., orcid.org/0000-0002-6991-0235
1 -Запорізький національний технічний університет, м. Запоріжжя, Україна, e-mail: turpak@i.ua

2 - Державний вищий навчальний заклад „Національний гірничий університет“, м. Дніпро, Україна

3 - Державний економіко-технологічний університет транспорту, м. Київ, Україна

\section{ЛОГІСТИЧНА ТЕХНОЛОГІЯ ДОСТАВКИ СИРОВИНИ ДЛЯ МЕТАЛУРГІЙНОГО ВИРОБНИЦТВА}

Purpose. To formalize logistic systems and technologies concerning the management of cargo delivery in terms of metallurgical production taking into consideration interaction between motor transport and railway transport. It is required to develop a logistic technology to manage transport generalizing efficiency indices and making it possible to optimize functioning of general transportation system of an enterprise.

Methodology. System analysis and logistic approach have been used. Transportation system of an enterprise has been analyzed from the viewpoint of logistics. The analysis makes it possible to integrate efficiency indices of functioning of certain subsystems of the general micrologistic system. Objective function and general model of transportation system optimization have been determined.

Findings. Logistic technology providing optimization of the parameters of transportation system functioning according to general logistic criterion has been represented. Micrologistic systems have been singled out; tendencies to control the delivery aimed at providing functional efficiency of transportation system of an enterprise have been determined. Parameters and factors determining the parameters of transportation efficiency to the fullest extent being the basis of developing logistic transportation systems of enterprises have been identified. 
Originality. A system to control enterprise transport has been formalized from the viewpoint of a system approach and logistic technology providing high-efficiency transportation has been determined. Management efficiency is estimated according to the logistic criterion involving all expenses connected with cargo delivery.

Practical value. A system of managerial decision-making has been developed. The system is based upon logistic technology optimizing functional parameters of the enterprise transport.

Keywords: metallurgical enterprise, logistic technology, system, cargo flow

Introduction. Following peculiarities are typical for a metallurgical enterprise structure:

- large production volumes requiring transportation and processing of considerable amounts of raw material, different types of materials, semi-products, equipment, fuel, refractory materials, and waste [1];

- vast territory and length of railroads;

- great capacity of certain facilities (blast furnaces, converters, Martin furnace, bloomings and slabbers) and their close transportation-technical and energy connections.

Depending upon their structures, metallurgical enterprises can be divided into several types. Metallurgical enterprises involving one basic process stage belong to plants. The main type of modern metallurgical plant is a plant with a complete cycle; such a plant includes blastfurnace, steel melting (Martin, converter, electric-furnace melting) and rolling shops.

If enterprises have some additional productions belonging to other industrial fields (mining, coke-chemical, production of refractory materials, etc.), they are called integrated works. Correspondingly, the structure of railroad management at the enterprises of different types differs considerably.

Railroad shops are the basic form of railroad management at the industrial enterprises. In terms of great volumes of transportation, railroad administrations (RRA) are established.

RRA management consists of a head, his/her deputies, chief engineer, safety supervisors, and workshop chiefs.

The administration may include operational shops, shops of rolling stock maintenance, running-maintenance shops, and track repair shops; freight (locomotive, and car) service, services of hoisting-transportation facilities, loading-unloading facilities, signaling and communication facilities, material and technical supply facilities, etc. Moreover, RRA structure (of railway shop) may also establish different subdivisions (departments, sites, bureaus). Some of them report to RRA management only in terms of their activities; in terms of administrative issues, they report to corresponding subdivisions of the enterprise (e.g. HR department, customer's service department, bookkeeping department, etc.).

According to functional classification, RRA is rather auxiliary than basic subdivision. From the production viewpoint, its task is to complete transportation orders. However, under the current conditions, functional duties of transportation subdivision are quite wider as they are connected with both raw-material suppliers and consumers of end product.

More qualitative and modern approach to the formation of a management transportation structure in the context of metallurgical enterprises involves the establishment of management transportation and logistics centers (Fig. 1 represents the prospective structure of the centers).

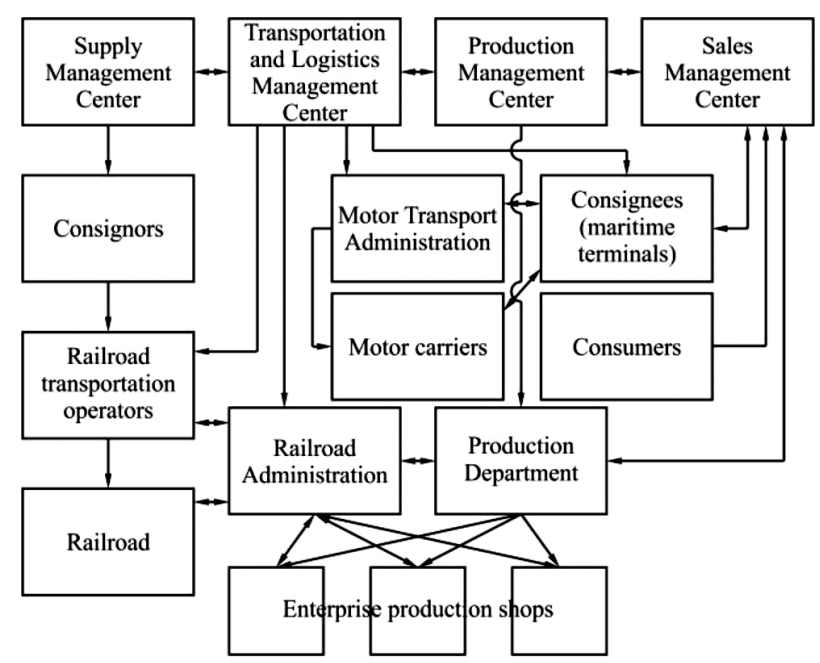

\section{Fig. 1. Prospective system of transport management of a metallurgical enterprise}

In this case, role of transport is not underestimated and problems of supply, production, sales, and transportation of cargos of an enterprise are combined by means of logistic approach to their solution.

Previously, contract activities were reduced to periodical (sometimes, one contract per several years) signing of agreements with railway (additional agreements) for the maintenance of entry line of an enterprise and resigning of agreements to service counterparties. Currently, the activities are represented by the numerously increased scopes of interaction with operators and car owners when there are many alternatives for certain cargo delivery involving integrated consideration and approval with all participants of the process (consignors, consignees, etc.). Analysis of various systems of enterprise transportation services involves their integrated assessment and selection of the most rational of them.

Analysis of the recent research. Current research in the field of transportation optimization in the context of metallurgical enterprises depends on the changes in certain production technological processes as well as transportation-technological processes. Transition to market relations has changed drastically the approach to incoming quality inspection and quantity of raw material. Qualitative changes also concerned the approach to processing of end product and its packing as well as execution of the orders. The number of operations in terms of many links of logistic supply chains has increased; connections among components of transportation systems of metallurgical enterprises have complicated. Rapid development of IT has resulted in significant increase of information volumes concerning transport-technological processes which involves applied research carrying out 
to analyze, forecast, and schedule transportations, efficient use of resources, etc.

Nowadays there are many possibilities to use modern optimizing techniques which depend on the creation of software and high-performance computers.

As before, problems of industrial transport depend upon the necessity to cut the terms of cargo delivery while minimizing resources providing movement of the material flows. However, conditions of the problems experience constant changes; that is why results of previous research are less and less topical.

Major current scientific problem is the need in a great number of applied developments for the new environment of transportation management which comparative analysis makes it possible to stimulate a new stage in the sphere of efficient functioning of transportation systems of metallurgical enterprises.

Currently, solution of transportation problems all over the world involves logistic approach [2-7]. Logistic chain is divided into micrologistic local sections which, in turn, may also be divided into further portioning.

Transportation system of a metallurgical enterprise combines a number of processes: cargo transportation by means of railway cars and motor vehicles; processes of cargo processing, transportation means, and documentation; cargo operations; and interaction with production and other types of transport.

Main objective of the systems engaged in management of enterprise transport processes is to form logistic chains and uniting of functional modules of the system for their efficient functioning.

First of all, efficiency is timely delivery of cargos (raw materials, fuel, materials, etc.) to the production subdivisions and warehouses of an enterprise; timely empty car supply to loading points in terms of meeting the requirements for documentation regulating the operations (standards on labour protection and safe railway operation, in-plant transportation schedules to service shops, etc.).

Minimization of specific cost per unit of transportation operations and improvement of other operation indices of transport (decrease in transportation cost and fee for the use of railway cars, etc.) is another efficiency index.

Moreover, efficiency is the improvement of such indices as a degree of complex labour mechanization, decrease in the number of transport safety rules violations as well as the improvement of technological infrastructure.

The problem is in the nonavailability of a technology optimizing delivery processes which would agree all the efficiency indices.

Objectives of the article. Objectives of the system of delivery processes management are achieved by means of solving a complex of logistic problems; the complex includes the three levels: global, general, and separated ones.

Global level involves solving the problem of rational and balanced use of resources of transportation system when common cost for transportation and execution of associate technological operations is minimal, and operation schedules are timely and complete.

General level involves solving following problems:

- development of optimal routes of trains in the context of an enterprise;
- optimization of distribution of own rolling stock for transportations;

- determination of optimal quantity of cars in trains and in the transfer trains;

- optimization of car fleet sizes as for the types of the enterprise rolling stock;

- optimization of resource distribution (loading-unloading machines, locomotives, etc.);

- optimization of warehouse supplies.

Separated level involves following optimization problems:

- cargo arrangement within a rolling stock;

- order picking;

- cargo processing and cargo placing within warehouses;

- selection of rolling stock of railroads or operator companies engaged in transportation of certain cargos;

- operation of transport during cold seasons;

- setting a priority of transportation means servicing;

- management of processes of interaction with other types of transport and production.

The problems should be solved in the context of coordinated operations of transportation subdivisions, production subdivisions, and subdivisions engaged in preproduction.

Formation of logistic technology to deliver raw material for metallurgical production is a topical scientific problem to be solved.

Statement of basic material. Formalization of the logistic system. A structure of an enterprise management is of utmost importance to implement logistic approach in the process of cargo delivery control. Previously, enterprises of metallurgical industry solved transportation problems with the help of railway transport or railway (transportation) shops. Sometimes, the problems were solved by sales or production subdivisions. The most successful idea was to establish transportation management centers being transformed now into logistics and transportation management centers formulating the sphere of their authorities and functions more exactly.

Sphere of logistic approach application integrates different types of systems. It may be either within enterprises or within the whole cities. From the viewpoint, different types of logistic systems can be separated: from micrologistic to macro- and mesologistic. It is possible to consider transportation systems for metallurgical enterprises from different perspectives of logistic approach.

The systems may be considered as a part (subsystem) of complicated and large systems, e.g. sales and industrial groups. Such systems are beyond the research in the sphere of industrial transport.

As for the classification of inbound and outbound transportation flows, micrologistic system of industrial transport of a metallurgical enterprise usually consists of the two subsystems: railway transport and motor car transport.

Typical feature of the fact is that to compare with a subsystem of motor car transport, subsystem of railway transport is larger in its scale, structure, the number of processes taking place in it and their complexity.

Formalization of micrologistic subsystems of an enterprise transport. Logistic chain of a metallurgical enter- 
prise starts from the points of delivery of raw material, fuel, production material and finishes with the points of end product consumption.

Middle part of the chain performs processes of transfer of cargos, transportation means as well as information within the enterprise; that is why they are the most controllable from the viewpoint of management apparatus. The systems within which the processes take place are transportation-production ones; their performance is provided by industrial transport, and the largest transportation volume of their operations is performed by the enterprise railway transport.

Fig. 2 demonstrated a structure of the outbound cargo flows of a metallurgical enterprise.

As a rule, main points of cargo flow origination are located at the distance of up to $300 \mathrm{~km}$ from an enterprise; however, there are points located at the distance of several thousand kilometers. The more the transportation distance is, the less accurate the forecasting of transportation period is; hence, processes of their movement control are more complicated. Under such conditions it is especially difficult to control loaded car flows which are not routed.

Fig. 3 shows a structure of outbound railway car flows and motor car flows.

Information (documentation) flows accompany the material (cargo flows, railway car flows) advancing them. Thus, information as for the expected time of railway car departure as well as their number is coordinated with the consignor, and information as for the further movement of the railway cars may be obtained from the transportation operator or railway administrations.

Paper documentation is being gradually replaced with e-documentation which provides continuous movement of material flows.

Consequently, it is expedient to separate micrologistic subsystem of outbound flow servicing and a system of inbound transportations within a structure of general micrologistic system (MLS) of an enterprise.

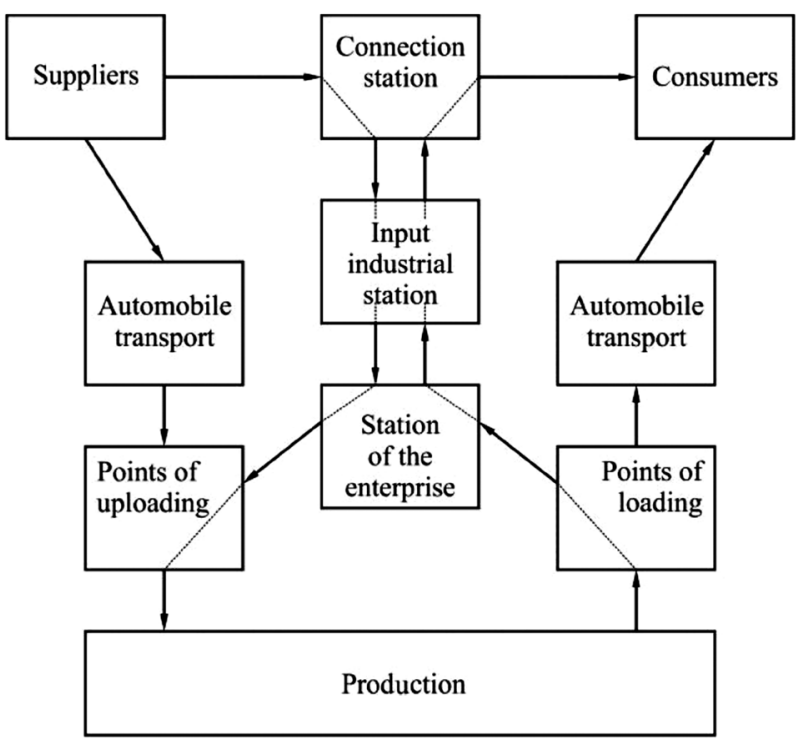

Fig. 2. Structure of outbound cargo flows of a metallurgical enterprise

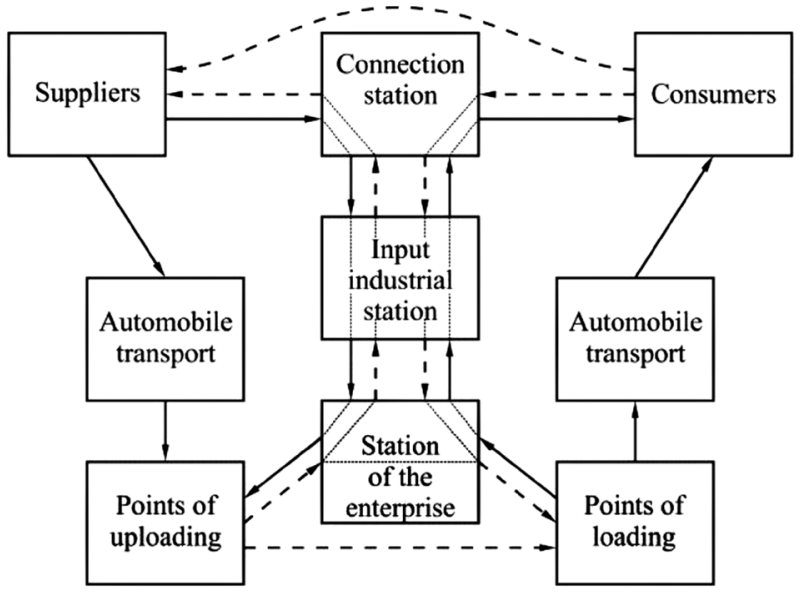

Fig. 3. Structure of outbound railway car flows and car motor flows:

$\longrightarrow-$ flow of loaded wagons; - - - - flow of empty wagons

Subsystems of outbound flow servicing are divided into subsystems of interaction with main railway transport (SIMRT) and subsystems of interaction with industrial transport of other enterprises (SIITOE).

Transportation processes in the context of SIMRT and SIITOE are similar; SIITOE differs in the following:

- decentralization of incoming product inspection points;

- cargo receipt in terms of their quantity and quality means common participation of the representatives of neighbouring enterprises. That excludes long idle-time period of transport means while waiting for the arrival of experts to coordinate the receipt result, if certain missing takes place or product is of inappropriate quality;

- as a rule, specialized rolling stock of own enterprise fleet is applied for the transportations; thus, procedures of inspections and preparation for transportation etc. may be simplified considerably;

- process of cargo batches delivery can be considered as determinative since they subject less to stochastic effect of external factors. That favours efficient planning of transportation operations;

- as a rule, the procedure of commercial inspection and completing transportation documentation is simplified.

Transportation within SIMRT means movement of trains with homogeneous cargos (route trains) and trains with nonhomogeneous cargos. Technological processes of such railway car processing differ greatly. Homogeneous cargos can move from the connecting station to the end unloading point of a metallurgical enterprise without processing within the supply route.

Trains with nonhomogeneous cargos (and various destination points) need sorting, accumulating on station railroads, forming trailing position with other railway cars, etc.

That is why SIMRTs are divided into subsystems with the movement of trains transporting homogeneous cargos mainly from one destination point and subsystems with transportation of trains with cargos for different destination points. 
Fig. 4 demonstrates classification of systems of general micrologistic system according to functional and organizational features.

The subsystems represented in the Figure consist of modules which physically are transportation and loading complexes, railway stations, etc.

In turn, the modules consist of the components - fleets or separate railroads, loading fronts, facilities to restore looseness, etc.

Each module is characterized by inputs and outputs; besides, they have certain integrity. To compare with the notion of "black box" in cybernetics, a module is an object in which not only dependence of outputs upon inputs is known. If necessary, there is a possibility to analyze the processes taking place in it. However, under certain conditions such a necessity may not be available.

Modules can be used to separate systems of raw material delivery, transportation of end product, etc.

Fig. 5 represents a structure of interaction spheres of micrologistic system of an enterprise.

Thus, by means of such system analysis methods as decomposition and graphic representation, general microlo-

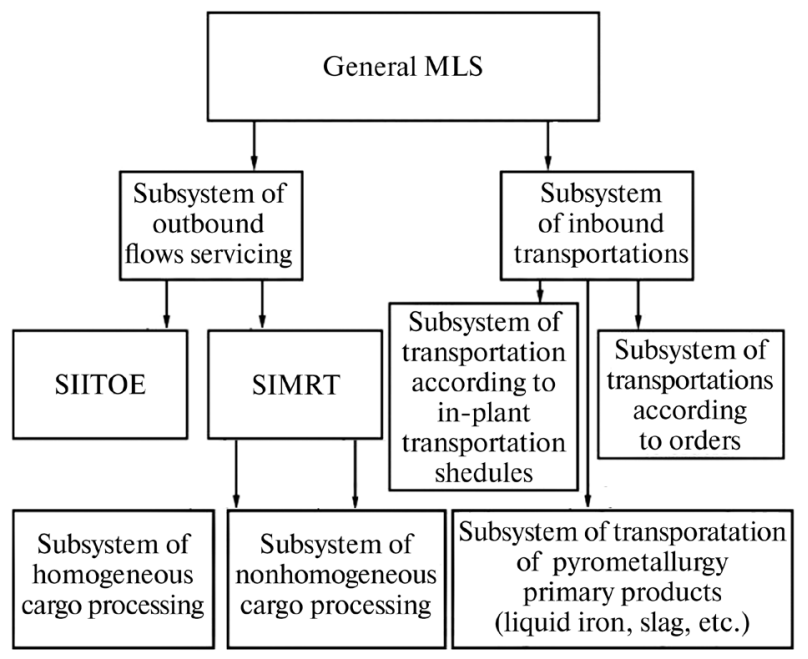

Fig. 4. Classification of general micrologistic system according to functional and organizational features gistic system has been singled out, and its place, interaction sphere with other systems, basic functional links and a structure of lower-level subsystems have been determined.

Implementation of managerial decisions. Basic average-term and long-term problems of transportation process management of an enterprise are as follows:

- stage-by-stage technical progress and prospective re-equipment of railway stations, car and locomotive fleets, loading fronts, means of automation and communication, etc.;

- implementation of measures to cut the consumption of combustible and lubrication materials as well as energy;

- improvement of transport technological processes, shortening the terms of cargo delivery within an enterprise;

- IT development;

- improvement of the efficient of interaction between production and transport, stock control;

- improvement of legislative relations with the subjects of major railway transport.

Main problems of operative management of transportation processes are the following:

- technological transportation of primary products of pyrometallurgy: hot agglomerate, hot iron, slag, steel, hot ingots;

- implementation of in-plant transportation schedules;

- provisions of effective transportation service of shops while implementing daily production plan;

- meeting the terms of railway car staying within entry lines;

- meeting the terms of circulation of local fleet cars which are not used for transportations within the in-plant schedules;

- maximally efficient use of available resources in terms of productivity.

It is possible to single out certain subsystems within micrologistic system of an enterprise. In turn, the subsystems may also be considered as the systems with all the features typical for them including the possibilities for further portioning. End result of the portioning is the system component. In the context of new component

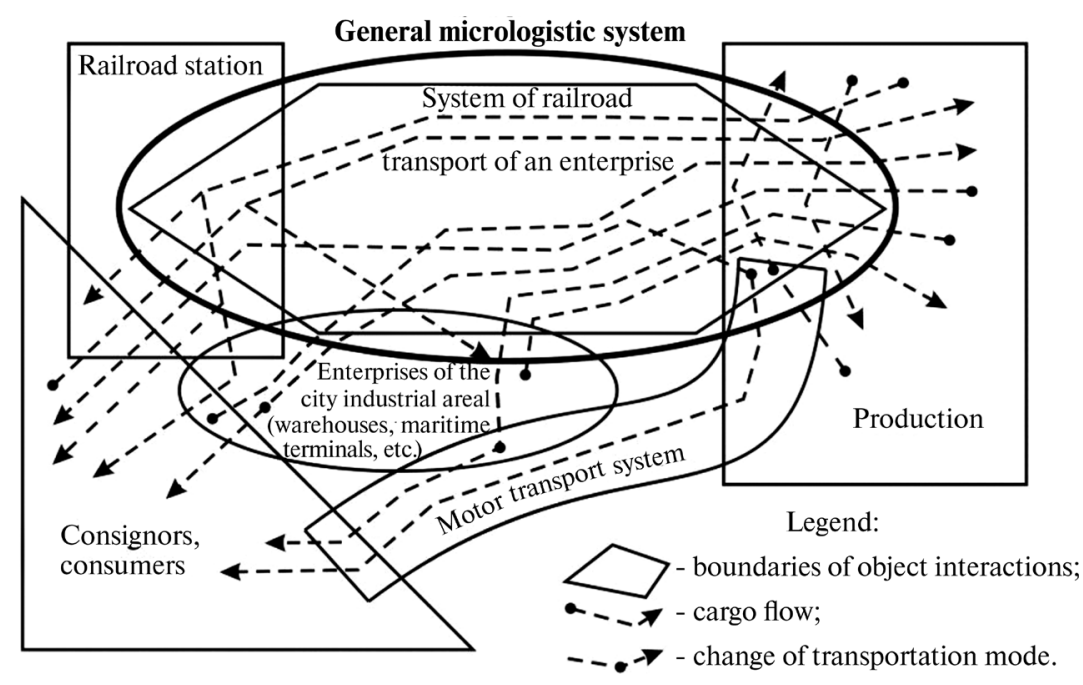

Fig. 5. Spheres of interaction of general micrologistic system of an enterprise 
origination or liquidation of the available one and changes in certain operational parameters, reorganization of its certain subsystems is required rather than reorganization of the whole system. Fig. 6 shows functional and information structure of management of enterprise transport subsystems.

A subsystem (e.g., industrial station, fleet of railroads or loading point) gets controlling signals from the subsystem management; the signals are produced relying upon information exchange with other subsystems [8], controlling signals from the systems of higher level and feedback with the subsystem under control.

Flows of cargos and cars enter the system; they are processed according to certain transport-technological procedure [9] and transferred to other systems.

Separate subsystem is under the effect of various random factors which change considerably the parameters of its components for a definite period of time (violations of operations, breakage of hoisting-transportation machines and other equipment, damage of transport means, emergency situations, etc.).

Objective function. Logistic criterion is a criterion of efficient functioning of the transportation system of a metallurgical enterprise. The criterion involves:

- management cost $C_{\mathrm{y}}$;

- operational cost to deliver cargos and perform processes stipulated by the delivery (e.g., car cleaning after their unloading, warehouse reloading, etc.) $C_{\mathrm{e}}$;

- cost resulting from nondelivery within the specified term or benefit resulting from shortening terms of cargo delivery $C_{\mathrm{T}}(P)$;

- cost or benefit from interaction with other types of transport $C_{\mathrm{B}}$.

Objective function becomes

$$
z=f\left[C_{\mathrm{y}}(P) ; C_{\mathrm{e}}\{(P ; y(P)) ; V(P)\} ; C_{\mathrm{T}}(P) ; C_{\mathrm{B}}(P)\right] \rightarrow \min ,
$$

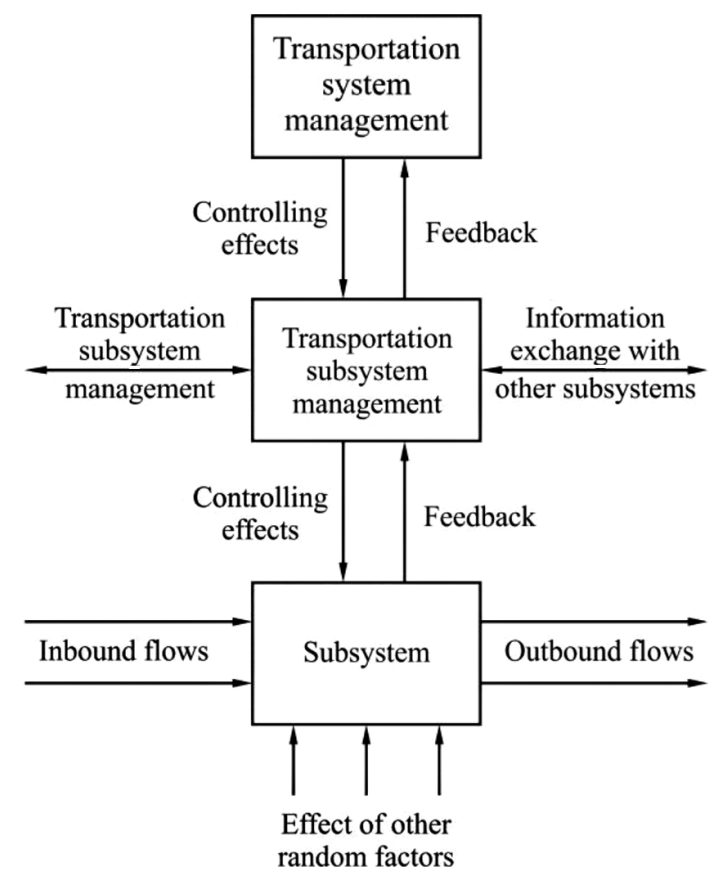

Fig. 6. Functional and information management structure in terms of the limitation

$$
a_{i} \leq P_{i} \leq b_{i},(i=\overline{1, n}),
$$

where $P$ is the totality of $n$ resources providing cargo delivery within micrologistic system of an enterprise and execution of the processes depending upon the delivery, $P=\left(P_{1}, P_{2}, \ldots, P_{n}\right) ; P_{i}$ is the volume of $i$ th resource use (in terms of locomotive-hours, machine-hours, man-hours etc.); $y(P)$ is a function of changes in the value of a unit of $i^{\text {th }}$ resource depending upon its volume, UAH (it takes into consideration different variations of fee calculation by transportation operators and railway for the use of the cars); $V(P)$ is a value parameter of the cargo losses while $i^{\text {th }}$ resource using (e.g., in terms of extra reloading within a warehouse, etc.), UAH; $a_{i}$ and $b_{i}$ are minimum and maximum limits of $i^{\text {th }}$ resource use respectively.

As for the widely used concept of consolidated structure of logistic system of a metallurgical enterprise, one of which variants is represented in paper [10], its main components (according to the order of material flow movement) is a system of supply of raw material, fuel, equipment, and other materials for production, a system of technological complex of an enterprise, and a system of end product consumption. From the theoretical viewpoint, micrologistic system is a part of a system of technological complex of an enterprise as a part of general logistic system.

Fig. 7 explains functional and organizational structure of general micrologistic system.

In terms of functional and organizational as well as technological features, general micrologistic system of a metallurgical enterprise is divided conditionally into the planes being its subsystems, where cargo flows and projections of infrastructure objects are indicated. The represented structure is a graphic model of a general micrologistic system.

Formulation of major problems of transportation process management is based upon the execution of main indices of transport operations. Key tendency of the efficient management is maximum use of the available resources (logistic tools) in terms of minimization of logistic cost to deliver cargos.

Main resources include locomotives, railway cars, hoisting and transportation machines, railroad development, maintenance and servicing points, equipment etc. Railway car is the component of transportation system moving the cargo.

Key indices of efficient car operation are as follows:

- timely transportation using special-purpose rolling stock (heated cargos including melts);

- degree of in-plant transportation schedules implementation at an enterprise;

- period of major fleet cars staying within the entry line of an enterprise;

- idle period of local fleet cars within the industrial stations where there are no in-plant transportation schedules.

Conclusions and recommendations for further research. Logistic chain of raw material delivery to metallurgical enterprises has been considered. While using such methods of system analysis as decomposition and graphic representation, general micrologistic system of an enterprise 


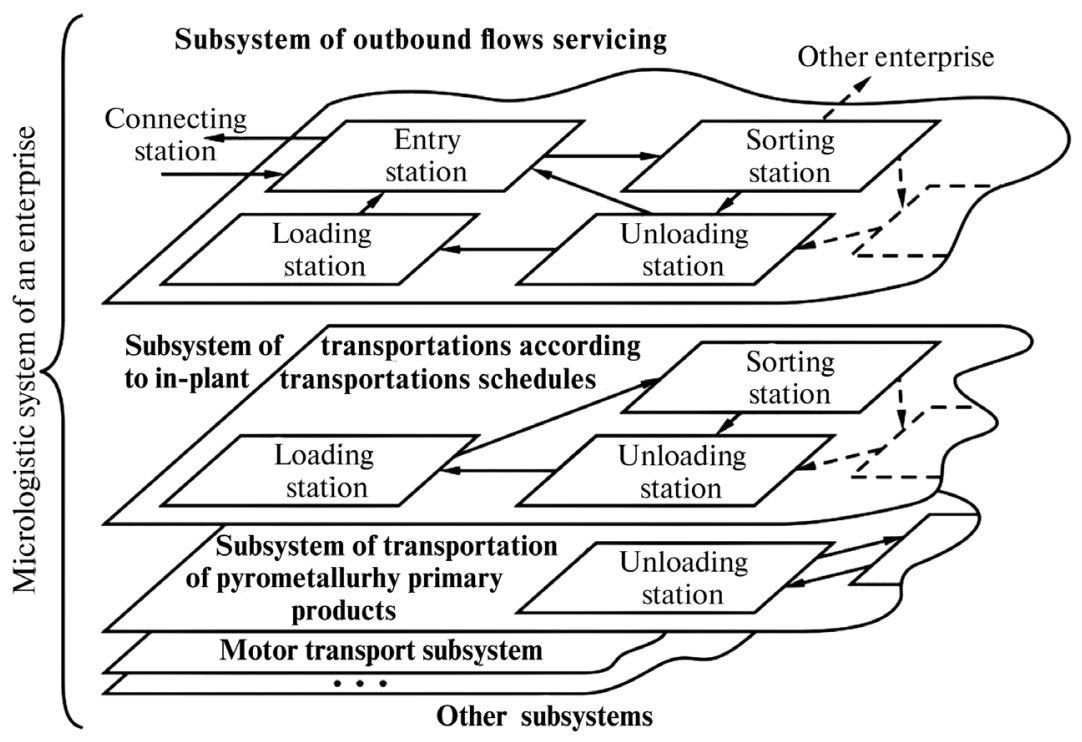

Fig. 7. Functional and organizational structure of a general micrologistic system

has been singled out. Its place, interaction spheres with other systems, basic functional connections and a structure of low-level subsystems have been determined. Logistic system has been analyzed; its basic objective and problems of its optimization have been identified.

Cargo flow structure and a system to manage subsystems of metallurgical enterprise transportation have been formalized.

Logistic optimization criterion has been developed. The criterion involves the following: managerial cost, operational cost for cargo delivery, cost resulting from nondelivery within the specified term (benefit resulting from shortening terms of cargo delivery); cost (benefit) resulting from interaction with other types of transport. Objective function has been determined.

Further research is planned mainly in the field of deepening the analysis of internal connections of transportation systems, determining additional (hidden) influential factors, and improving scientific developments towards the increased "flexibility" and accuracy of the results.

\section{References.}

1. Gritcay, S., Lashenyh, A., Turpak, S., Ostrohlyad, E. and Kharchenko, T., 2017. The effect of methods of eliminating spikes in the time series of freight flows on their statistical characteristics Eastern-European Journal of Enterprise Technologies, 1/3(85), pp 33-39.

2. Anbuudayasankar, S.P., Ganesh, K. and Mohapatra, S., 2014. Models for Practical Routing Problems in Logistics. Design and Practices Springer International Publishing, Switzerland.

3. Blanchard, D., 2010. Supply chain management: best practices. Wiley. Available at: <http://lib.vcomsats.edu. pk/library/MGT563/Course\%20Contents/HANDOUTS/SCM\%20Best\%20Practices.pdf> [Accessed 27 December 2017].

4. Stocchetti, A. and Scattola, E., 2011. Supply chain management in industrial production. A retrospective view. MPRA, University Library of Munich, Germany, 1(09), 872, pp. 45-66. Available at: <https://mpra.ub.uni-muenchen. de/33094/> [Accessed 27 December 2017].

5. Stadtler, H., Kilger, C. and Meyr, H., 2015. Supply Chain Management and Advanced Planning: Concepts, Models. Software, and Case Studies, Springer.

6. Kolga, A., Rakhmangulov, A., Osintsev, N., Sladkowski, A. and Stolpovskikh, I., 2015. Robotic transport complex of automotive vehicles for handling of rock mass at the process of open cast mining. Transport problems, 10/2, pp.109-116.

7. Coyle, John J., Novak, R. and Gibson, B., 2013. Transportation: A Global Supply Chain Perspective. Amason : Kindle Edition.

8. Bulgakova, J., 2016. Decision making on cargo-flows management in integrated production and transportation system. Transport problems, 11/4, pp. 83-94.

9. Lashenyh, A., Turpak, S., Gritcay, S., Vasileva, L. and Ostrohlyad, E., 2016. Development of mathematical models for planning the duration of shunting operations. Eastern-European Journal of Enterprise Technologies. 5/3(83), pp. 40-46.

10. Parunakjan, V. and Sizova, E., 2013. Designing of logistical chains inside production and transport system of metallurgical enterprise. Transport problems, 8/1, pp. 35-45.

Мета. Формалізувати логістичні системи й технології управління доставкою вантажів в умовах металургійного підприємства з урахуванням взаємодії автомобільного й залізничного транспорту. Розробити логістичну технологію управління транспортом, що узагальнює показники ефективності й дозволяє виконати оптимізацію функціонування загальної транспортної системи підприємства.

Методика. Застосовано системний аналіз і логістичний підхід. Виконано аналіз транспортної системи підприємства з позицій логістики, що дозволяє інтегрувати показники ефективності функціонування окремих підсистем загальної мікрологістичної системи. Визначені цільова функція й загальна модель оптимізації транспортної системи. 
Результати. Представлена логістична технологія, що забезпечує оптимізацію параметрів функціонування транспортної системи за загальним логістичним критерієм. Виділені мікрологістичні системи, визначені напрями управління доставкою з метою забезпечення ефективності функціонування транспортної системи підприємства. Встановлені параметри й фактори, які найбільшою мірою визначають показники ефективності перевезень, що є базою для створення логістичних систем транспорту підприємств.

Наукова новизна. Формалізована система управління транспортом підприємства з позицій системного підходу й встановлена логістична технологія, що забезпечує високу ефективність перевезень. Оцінка ефективності управління виконується за логістичним критерієм, що враховує всі витрати на доставку вантажів.

Практична значимість. Розроблена система прийняття управлінських рішень, що базується на логістичній технології оптимізації параметрів функціонування транспорту підприємства.

Ключові слова: металургійне підприємство, логістична технологія, система, вантажопотік

Цель. Формализовать логистические системы и технологии управления доставкой грузов в условиях металлургического предприятия с учетом взаимодействия автомобильного и железнодорожного транспорта. Разработать логистическую технологию управления транспортом, обобщающую показатели эффективности и позволяющую выполнить оптимизацию функционирования общей транспортной системы предприятия.

Методика. Применен системный анализ и логистический подход. Выполнен анализ транспортной системы предприятия с позиций логистики, позволяющий интегрировать показатели эффективности функционирования отдельных подсистем общей микрологистической системы. Определены целевая функция и общая модель оптимизации транспортной системы.

Результаты. Представлена логистическая технология, которая обеспечивает оптимизацию параметров функционирования транспортной системы по общему логистическому критерию. Выделены микрологистические системы, определены направления управления доставкой с целью обеспечения эффективности функционирования транспортной системы предприятия. Установленные параметры и факторы, которые в наибольшей степени определяют показатели эффективности перевозок, являются базой для создания логистических систем транспорта предприятий.

Научная новизна. Формализована система управления транспортом предприятия с позиций системного подхода и установлена логистическая технология, которая обеспечивает высокую эффективность перевозок. Оценка эффективности управления выполняется по логистическому критерию, который учитывает все расходы на доставку грузов.

Практическая значимость. Разработана система принятия управленческих решений, основанная на логистической технологии оптимизации параметров функционирования транспорта предприятия.

Ключевые слова: металлургическое предприятие, логистическая технология, система, грузопоток

Рекомендовано до публікації докт. техн. наук B.I. Самусею. Дата надходження рукопису 13.12.16. 